\title{
Larvicidal activity of essential oil of Etlingera fenzlii (Kurz) Skronick. \& M. Sabu (Zingiberaceae) - The honey bee repellent endemic plant species of the Andaman Nicobar Islands
}

\author{
Anju $\mathrm{S}^{\mathbf{1}}$, Aneesh $\mathrm{E} \mathrm{M}^{2}$ and Radha $\mathrm{R} \mathrm{K}^{\mathbf{1}^{*}}$ \\ ${ }^{1}$ Biotechnology and Bioinformatics Division, Jawaharlal Nehru Tropical Botanic Garden and Research Institute, Palode, \\ Thiruvananthapuram 695562, India \\ ${ }^{2}$ Communicable Disease Research Laboratory, St. Joseph’s College, Irinjalakuda, Thrissur 680121, India

\section{Article history} \\ Received: 09 May 2018 \\ Accepted: 07 July 2018 \\ Published: 17 July 2018 \\ Editor \\ Veena S Anil, University of \\ Agricultural Science, GKVK, \\ Bangalore, India

\begin{abstract}
Etlingera fenzlii (Kurz) Skronick. \& M. Sabu (Zingiberaceae), is an endemic species of the Andaman Nicobar Islands which is exclusively used by the Shompens as a bee repellent for honey collection. The essential oil obtained by hydrodistillation of leaves of $E$. fenzlii and the volatile constituents of leaves have proved to be effective eco-friendly and possess varying degrees of insect/ pest controlling properties. The present study was focussed on the role of larvicidal activities of the essential oil of E. fenzlii against Aedes aegypti. Larvicidal study was carried out employing WHO standard method and the mortality was observed after 24 $h$ exposure. Larvicidal tests were carried out with the essential oil concentration ranges from 5-50 ppm. Essential oil treatment had higher mortality as compared to control with $\mathrm{LC}_{50}$ value of $11.22 \mathrm{ppm}$. From the results, it is evident that E. fenzlii can be considered as effective larvicide, signifying an ecofriendly method for the control of mosquito vectors.
\end{abstract}

\section{Publisher}

Horizon e-Publishing Group

\author{
*Correspondence \\ Radha R K \\ $凶$ radhapkumar@rediffmail.com
}

Keywords: Essential oil; Etlingera fenzlii; Larvicidal activity; Aedes aegypti

Citation: Anju S, Aneesh E M, Radha R K. Larvicidal activity of essential oil of Etlingera fenzlii (Kurz) Skronick. \& M. Sabu (Zingiberaceae) - The honey bee repellent endemic plant species of the Andaman Nicobar Islands. Plant Science Today 2018;5(3):121-125. https://dx.doi.org/10.14719/pst.2018.5.3.397

Copyright: (c) Anju et al (2018). This is an open-access article distributed under the terms of the Creative Commons Attribution License, which permits unrestricted use, distribution, and reproduction in any medium, provided the original author and source are credited (https://creativecommons.org/licenses/by/4.0/).

\section{Introduction}

Mosquitoes are important vector for transmission of many dreadful human diseases such as malaria, dengue fever, chikungunya and filariasis, and hence are consider the greatest health problems for humans across the globe $(1,2)$. Mosquito control is an utmost important step for the improvement of public health and controlling strategies are mainly by synthetic repellents. Most of the synthetic repellents are organochlorine and organophosphate compounds. Application of the chemical repellents causes many environmental problems and insecticidal residues often enter into ecosystem. Synthetic organic insecticides used for mosquito control have ill effects on environment, affect non-targets organisms and several species of mosquitoes have developed resistance (3-6). Now, researchers are mainly focusing on natural plant based insecticides and natural biodegradable insecticides from plants to control insect vectors of diseases and are found to be very effective (7-9). Phytochemicals are ecofriendly and can be used in insect control ensuring maximum safety in any 


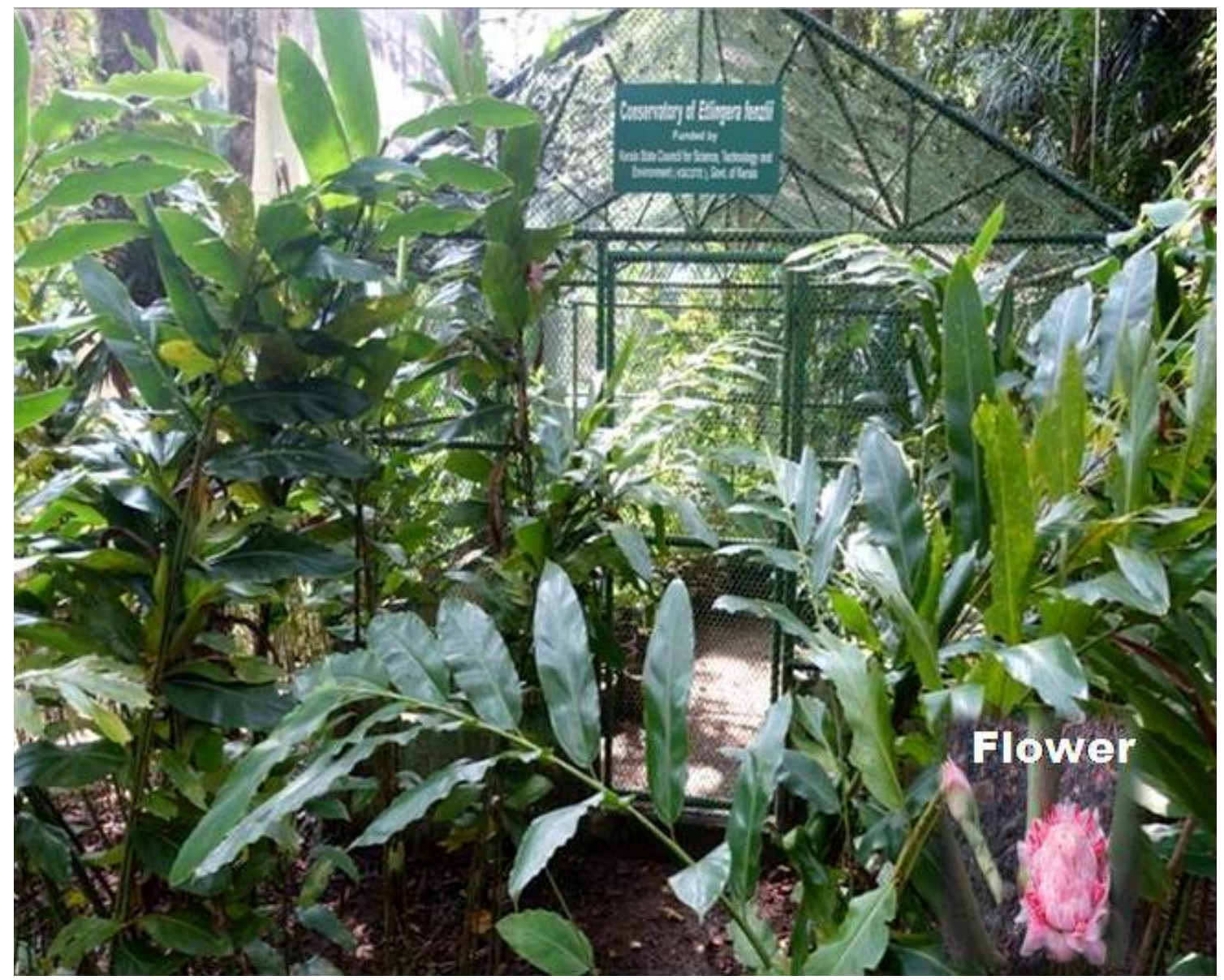

Fig. 1. Etlingera fenzlii - Mature plant

ecological condition without affecting non target organisms. Dengue is the most important mosquito- borne disease in tropical countries but now it is present in Africa and Americas and this significant viral disease is easily spread by Aedes mosquitoes mainly by Aedes aegypti. Mosquito control programmes are mainly focussing on the larval stage in their breeding sites with natural larvicides, as adulticides destroy the adult population only (10). Manzoor et al reported the use of essential oil from Acorus calamus, Ocimum basilicum, Cymbopogan citrates and Saussrea lappa for controlling A. aegypti (11). Larviciding is an important method for the reduction of insect population before they emerge into adults $(12,13)$. Essential oils of many plants have mosquito larvicidal property, so the use of plant essential oils in insect/mosquito control is a bio control method for minimizing the hazardous effects of insecticidal compounds on the environment (1416).

Etlingera fenzlii (Kurz) Skronick. \& M. Sabu (Zingiberaceae), is an endemic species in the Andaman Nicobar Islands exclusively used by the local tribe, Shompens, as a bee repellent for honey collection (Fig. 1). Shompens are one of the primitive off shoots of the Mongoloid race believed to have migrated from Malayan peninsula. Shompens are one of the mangoloid tribes of Andaman Nicobar Islands and their major food is fruit of screw pines and honey from wild bees.
During their honey collection, they chew the plant parts of E. fenzlii and spit out the sap filled in the mouth as coarse spray on beehives which tranquilize the honey bees and protect them from bee stings (17). Roots and flower juice of E. fenzlii are also used to treat malarial fever, stomach disorders and gastro intestinal disorders. The chemical characterization on essential oils of the species carried out proved that E. fenzlii has effective repellent or tranquilizing property towards insects (18). In this context, the present study focuses on the larvicidal potential of essential oil of $E$. fenzlii against dengue vector $A$. aegypti.

\section{Materials and Methods}

Plant material: Plants were collected from Mount Harriet hill ranges of South Andamans, Nancowary Island, Katchal Island and Great Nicobar Island. Living plant collections are introduced in to the field gene bank of Jawaharlal Nehru Tropical Botanical Garden and Research Institute (JNTBGRI) and a voucher specimen was deposited in the herbarium of the Institute. Fresh leaves were collected, washed under running tap water and were used immediately to extract the essential oil.

Essential oil isolation: Fresh leaves (400 g) were hydrodistilled for $3 \mathrm{~h}$ using a Clevenger-type 


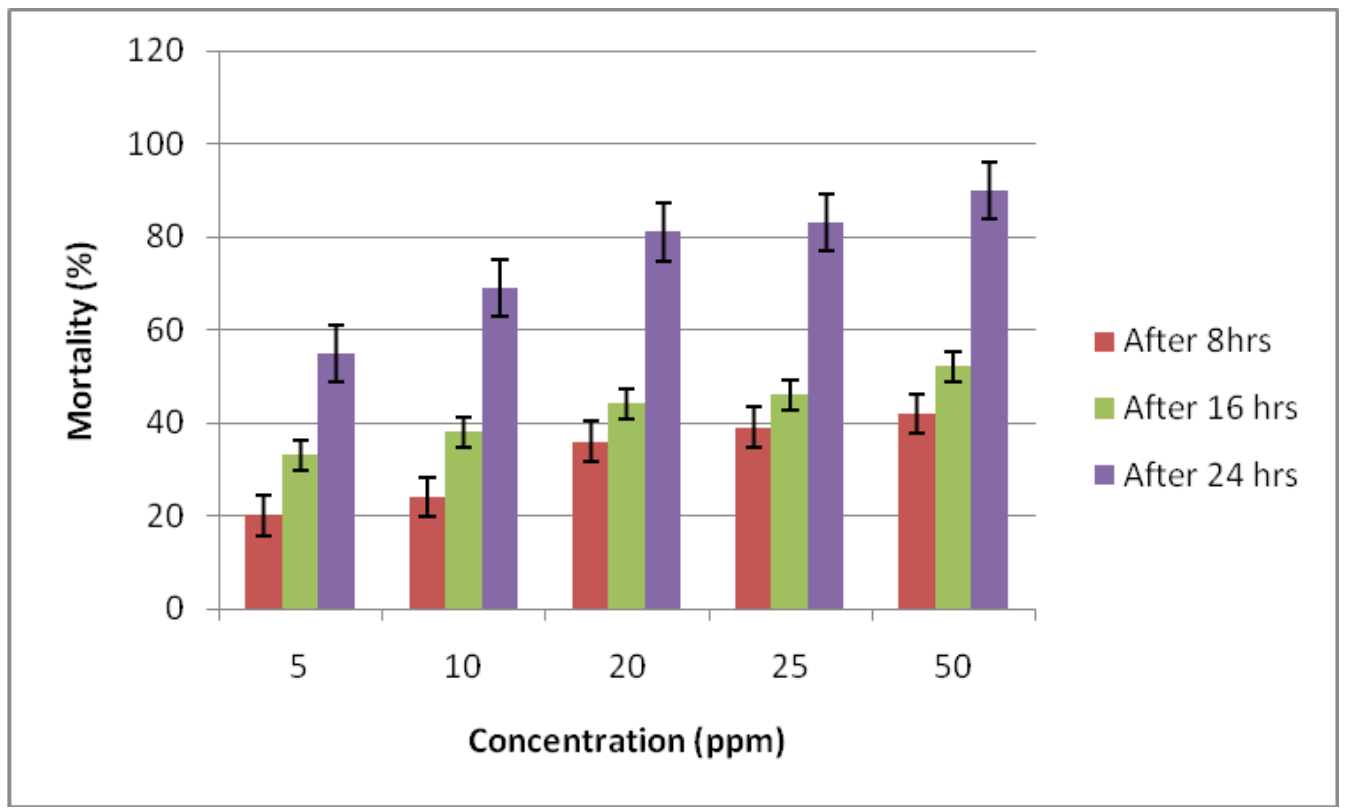

Fig 2. Percentage of mortality of essential oil of Etlingera fenzliiat different concentrations against fourth instar larvae of Aedes agypti.Values are mean \pm SD for five replications. Note: No mortality was recorded in control treatment (acetone)

apparatus to obtain the essential oil. The oil was collected and dried over anhydrous sodium sulphate $\left(\mathrm{NA}_{2} \mathrm{SO}_{4}\right)$ and stored at $10^{\circ} \mathrm{C}$ until analysed (19).

\section{Mosquito larval culture}

Larvae of A. aegypti used in the experiments were maintained in Communicable Disease Research Laboratory, St.Joseph's College, Irinjalakuda, Thrissur. In a pilot study, concentrations of 100 and 200 ppm shows hundred percentage mortality so in subsequent experiments the larvae were exposed to sub-lethal concentrations of 5, 10, 20, 25 and $50 \mathrm{ppm}$ of oil in $250 \mathrm{ml}$ distilled water according to WHO procedure (20). The essential oil was dissolved in acetone to make the stock solution. This stock solution was further diluted in water to make different concentrations. In addition to the treatments (in five replicates), the control containing $1 \mathrm{ml}$ acetone and distilled water (21) was included. The oil-acetone-water solution was stirred for $30 \mathrm{sec}$ with a glass rod. After about $15 \mathrm{~min}$, batches of 25 early fourth instar stage larvae were released into glass beakers of $500 \mathrm{ml}$ capacity containing $249 \mathrm{ml}$ of dechlorinated tap water and $1.0 \mathrm{ml}$ of essential oil. Control beakers contained 25 test organisms and $249 \mathrm{ml}$ of tap water along with $1.0 \mathrm{ml}$ acetone. Treated and control beakers were maintained at same conditions $\left(25 \pm 2^{\circ} \mathrm{C}\right)$ and twenty five larvae/concentration were used for all trials and were repeated five times. After treatment, treated larvae were observed and recorded their response at regular time intervals. The number of dead larvae in beaker was calculated at the end of $24 \mathrm{~h}$. Larvae were considered dead if they failed to respond to probing with a glass rod or fine needle, as described in the WHO technical report series (20).
Statistical analysis of the data was calculated with $\mathrm{LC}_{50}$ using Probit analysis. The percentage mortality was calculated by using the formula,

Percentage of mortality $=($ Number of dead larvae / Number of larvae introduced) $\times 100$

Mortality was reported as $\mathrm{LC}_{50}$, representing the concentrations in ppm with $50 \%$ larval mortality rate in $24 \mathrm{~h}$, respectively and $\mathrm{LC}_{50}$ was determined using Probit analysis (22).

\section{Results and Discussion}

The insecticidal nature of essential oil of E. fenzlii showed greater impacts on the development of fourth instar larvae of $A$. aegypti recording significant mortality. The essential oil induced complete mortality at concentrations of 200 and $100 \mathrm{ppm}$ in pilot study, therefore mortality rates were calculated at reduced concentrations of 5,10 , 20,25 and $50 \mathrm{ppm}$. The data pertaining to the larvicidal activity of essential oil are presented in Table 1.

The mortality percentages at 5, 10, 20, 25 and $50 \mathrm{ppm}$ were 55, 69, 81, 83 and $90 \%$ respectively and no mortality was recorded in control (acetone) treatment. The mortality rate of the mosquito larvae increased with the concentration of the oil (Fig. 2). A complete control over the larvae was recorded in case of higher dose of essential oil and overall larval mortality ranged from 55 to $90 \%$. The mortality percentage was lowest at $5 \mathrm{ppm}$ (55\%). These results confirm the potential to develop of new safe and more effective natural larvicides. Plant derived secondary metabolite is an alternative method for reducing the side effects of chemical repellents on the environment. Watanabe et al reported the 
Table 1: Larvicidal activity of essential oil of Etlingera fenzlii against fourth instar larvae of Aedes agypti after $24 \mathrm{~h}$ of treatment.

\begin{tabular}{cccccc}
\hline No & Concentration $(\mathrm{ppm})$ & $\log _{10}$ & Mortality $(\%)$ & Probit & $\mathrm{LC}_{50}$ \\
\hline 1 & 5 & 0.69 & 55 & 5.13 & \\
2 & 10 & 1 & 69 & 5.5 & \\
3 & 20 & 1.30 & 81 & 5.88 & 11.22 \\
4 & 25 & 1.39 & 83 & 5.95 & \\
5 & 50 & 1.69 & 90 & 6.28 & \\
\hline
\end{tabular}

Values are mean \pm SD for five replications

Note: No mortality was recorded in control treatment (acetone)

importance of some of secondary plant metabolites and also mentioned their repellent properties $(23,24,9)$. Bhatnagar et al studied the repellent properties of essential oils of Ocimum basilicum (L.) and Ocimum sanctum (L.) against Anophelis stephensi Liston, A. aegypti (L.) and Culex quinquefasciatus (Say) mosquito species under laboratory conditions (25). Manzoor et al also reported that the essential oil of Cymbopogan citrates and Saussrea lappa showed significantly higher larvicidal activity against $A$. aegypti and $C X$. quinquefasciatus (11). Essential oil of Cinnamomum osmophloeum had the best larvicidal activity against $A$. aegypti with an $\mathrm{LC}_{50}$ value was $29 \mathrm{ppm}$ (26). Vrushali et al evaluated the bioactivity of essential oil of Trachyspermum sp. against $A$. aegypti and southern house mosquito, $C X$. quinquefasciatus Say $\left(\mathrm{LC}_{50}=93.19-150.0 \mathrm{ppm}\right)$ (27). Our findings revealed that, the essential oil of $E$. fenzlii is effective in causing mortality of mosquito larvae with minimum lethal concentration and that it has potential for field use in mosquito control programme.

\section{Conclusion}

The use of plant-derived products, such as essential oils, in the production of natural larvicidal insecticides, could be a promising tool to reduce the spread of mosquito transmitted diseases. In addition, these products are biodegradable and express low toxicity towards non target organisms. In light of our present study, the essential oil of $E$. fenzlii considered as a rich source of ecofriendly bioactive compounds, may be considered as a safe natural repellent against mosquito larvae.

\section{Competing Interests}

There is no conflict of interest among the authors.

\section{Acknowledgements}

We thank the Director, Jawaharlal Nehru Tropical Botanic Garden and Research Institute for providing facilities. We are grateful to Dr Sam P Mathew, Scientist, JNTBGRI for collecting plant samples from Great Nicobar Islands. The authors acknowledge the Kerala State Council for Science Technology and Environment Committee, Government of Kerala for financial Support.

\section{Author's contributions}

All the authors contributed equally to prepare the article.

\section{References}

1. Govindarajan M. Larvicidal efficacy of Ficus benghalensis L. plant leaf extracts against Culex quinquefasciatus Say, Aedes aegypti L. and Anopheles stephensi L. (Diptera: Culicidae). Europ. Rev. Med. Pharmacol. Sci. 2010; 14: 107-11.

2. James AA. Mosquito molecular genetics: the hands that feed bite back. Science 1992; 257: 37-38. https:/l doi.org/10.1126/science.1352413

3. VCRC. Vector Control Research Centre (Ed. Rajagopalan, P.K.) Miscellaneous Publication 1989; 11: 26.

4. Junwei Z, Yanma ZX, Ting L, Kuen Q, Yuhua H, Suqin X, Tucker B, Schultz G, Coats J, Rowley W and Aijun Z. Adult repellency and larvicidal activity of five plant essential oils against mosquitoes. J. Amer. Mosqu. Contr. Assoc. 2006; 3: 515-22.

5. Bansal SK, Singh KV, Sharma S, Sherwani MR. Comparative larvicidal potential of different plant parts of Withania somnifera against vector mosquitoes in the semi-arid region of Rajasthan. J Environ Biol. 2011; 32(1): 71-75.

6. Devine GJ and Furlong MJ. Insecticide use: contexts and ecological successions. Agr Human Values 2007; 24: 281- 06. https://doi.org/10.1007/s10460-007-9067-z

7. Olaifa FE, Olaifa AK and Lewis OO. Toxic stress of lead on Clarias gariepinus (African catfish) Fingerlings. Afr. J. Biochem. Res. 2003; 6: 101- 4.

8. Nour AA, Elhussien SA, Osman AA and Nour AH. Repellent activity of the essential oils of four sudaneses accessions of basil (Ocimum basilicumL.) against Anopheles mosquitoes. Journal of Applied Sciences 2009; 9: 2645-68. https://doi.org/10.3923/jas.2009.2645.2648

9. Nathan SS. The use of Eucalyptus tereticornis Sm. (Myrtaceae) oil (leaf extract) as a natural larvicidal agent against the malaria vector Anopheles 
stephensi Liston (Diptera: Culicidae) Bio resource Technol. 2007; 98: 1856-60. https://doi.org/10.1016/j.biortech.2006.07.044

10. Hag EL, Rahman A, El-Nadi $\mathrm{H}$ and Zaitoon AA. Effects of methanolic extracts of neem seeds on egg hatchability and larval development of Culex pipiens mosquitoes. Indian Vet. J. 2001; 78: 199- 01.

11. Manzoor F, Samreen KB and Praveen Z. Larvicidal activity of essential oils against Aedes aegypti and Culex quinquefasciatus larvae. Journal of Animal and Plant Sciences 2013; 23(2):420-24.

12. Hardin JA and Jackson FLC. Applications of natural products in the control of mosquito-transmitted diseases. African Journal of Biotechnology 2009; 8: 7373-78.

13. Tiwary M, Naik SN, Tewary DK, Mittal PK and Yadav S. Chemical composition and larvicidal activities of the essential oil of Zanthoxylum armatum DC (Rutaceae) against three mosquito vectors. Journal of Vector Borne Diseases 2007; 44:198-04.

14. Phasomkusolsil S and Soonwera M. Potential larvicidal and pupacidal activities of herbal essential oils against Culex quinquefasciatus Say and Anopheles minimus (Theobald). Southeast Asian Journal of Tropical Medicine and Public Health 2010; 41(6): 1342-51.

15. Sutthanont NW, Choochote B Tuetum, Junkum A, Jitpakdi A, U. Chaithong D.Riyong and Pitasawat B. Chemical composition and larvicidal activity of edible plant-derived essential oils against the pyrethroid-susceptible and -resistant strains of Aedes aegypti (Diptera: Culicidae). Journal of Vector

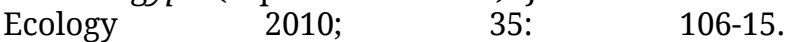
https://doi.org/10.1111/j.1948-7134.2010.00066.x

16. Fatope MO, Ibrahim H, Takeda Y. Screening of higher plants reputed as pesticides using the Brine Shrimp Lethality Assay. Int J Pharmacog. 1993; 31: 250-54. https://doi.org/10.3109/13880209309082949

17. Mathew SP, Radha RK, Krishan PN and Seeni S. Phytogeography of the Andaman- Nicobar Islands with special reference to Hornstedtia fenzlii (Kurz) K.Schum. Curr Sci 2010; 98:905-7.

18. Anju S, Radha RK. Evaluation of Acute and Dermal Toxicity of Essential Oil of Etlingera fenzlii (Kurz) K. Schum: An In Vivo Study. Int J Pharm Pharm Sci. 2016;8(7):69-72.
19. Anjana S and Thopil JE. Chemical composition of the essential oils of four Pogostemon spp and their larvicidal activity against Aedes albopictus Skuse (Diptera: Culicidae). International Journal of Environmental Biology 2013; 3(1):26-31.

20. WHO International travel and health vaccination requirement and health advice. World Health Organization, Geneva; 1995.

21. Xue RD, Barnard DR and Ali A. Laboratory and field evaluation of insect repellents as larvicides against the mosquitoes Aedes albopictus and Anopheles albimanus. Med Vet Entomol. 2001; 15:374-380. https://doi.org/10.1046/j.0269-283x.2001.00323.x

22. Finney D J. Ed. Probit Analysis. Cambridge, England, Cambridge University Press; 1952.

23. Watanabe K, Shono Y, Kakimizu A, Okada A, Matsuo $\mathrm{N}$, Satoh A, Nishimura H. New mosquito repellent from Eucalyptus camaldulensis. J Agri Food Chem. 1993; 41: 2164-66. https://doi.org/10.1021/jf00035a065

24. Vatandoost $H$ and Moinvaziri VM. Larvicidal activity of neem tree extract (Neemarin) against mosquito larvae in the Islamic Republic of Iran. Eastern Med Health J. 2004; 10: 573-78.

25. Bhatnagar M, Kapur KK, Jalees S and Sharma SK. Laboratory evaluation of insecticidal properties of Ocimum basilicum Linnaeus and $O$. sanctum Linnaeus plant's essential oils and their major constituents against vector mosquito species. J Entomol Res. 1993; 17(1): 111-19.

26. Cheng SS, Liu JY, Tsai KH, Chen WJ, Chang ST. Chemical composition and mosquito larvicidal activity of essential oils from leaves of different Cinnamomum osmophloeum provenances. J Agric Food Chem. 2004; 52(14):395-400. https://doi.org/10.1021/jf0497152

27. Vrushali T, Tare V and Shushil K. Bioactivity of some medicinal plants against chosen insect pests/vectors. In K Sushil, SA Hasan, D Samresh, AK Kukreja, S Ashok, AK Sharma, S Srikant and T Rakesh (eds.), Proceedings of the National Seminar on the Frontiers of Research and Development in Medicinal Plants, CIMAP, Lucknow; 2001. 